\title{
Agroforestry for restoration of degraded peatlands
}

\author{
Eni Maftu'ah*, Ani Susilawati and Yiyi Sulaeman \\ Indonesian Swampland Agriculture Research Institute (ISARI) \\ Jl. Kebun Karet, Loktabat, Banjarbaru, South Kalimatan, 70714, Indonesia
}

\begin{abstract}
The area of degreded peatlands in Indonesia is estimated at 4.4 million ha. Currently, the degraded peatland often a source of environmental problems, including sources of greenhouse gas (GHG) emissions and land fires. Restoration of degraded peatlands is intended to restore the value, function and benefits of the peat ecosystem, including efforts to prevent land damage, provide protection, and restore the ecosystem. One of the efforts to restore degraded peatlands is through revegetation. Agroforestry is a cropping pattern that uses a combination of tree crops with seasonal crops, and/or with livestock/fisheries activities. Agroforestry systems can be applied to degraded peatlands in production forest areas and other use areas. The advantages of agroforestry systems include; optimization of land, diversification of crops, reduce the risk of failure, can also prevent land preparation (for seasonal crops) with the burn system, and increase carbon stock. The success of an agroforestry system is very dependent on tree management which can reduce adverse effects and maximize the beneficial effects physically, economically, socially and environmentally. The selection of tree and agricultural plant types is important in order to restore degraded peatlands. The jelutung + pineapple agroforestry system provides physical, economic, social and environmental benefits. Jelutung + corn + horticultural crops are able to provide significant benefits. Agroforestry systems can be implemented to mitigate carbon emissions in degraded peatlands.
\end{abstract}

\section{Introduction}

Peatlands have the potential to be utilized, but must consider environmental functions (carbon storage, water reservoirs, habitat for flora and fauna), as well as their zoning. The area of peatland in Indonesia is 14.9 million ha, degraded around 4.4 million ha (3.7 million ha of scrub and 0.7 million ha in the form of open and ex-mining land) [1]. The rampant clearing of peatlands in the past has caused a lot of damage to the peatlands. According to [1] the area of degraded peatland is around 4.4 million ha (3.7 million ha of scrub and 0.7 million ha in the form of open and ex-mining land). Degraded peatlands are scattered in Sumatra, Kalimantan and Papua. Degraded peatlands are more susceptible to land fires, due

\footnotetext{
*Corresponding author: eni_balittra@yahoo.com
} 
to overdrain and land cover that is dominated by shrubs, making it easy to burn. Overdrained peat has caused the top layer of the peat to dry out and triggered land fires. Water management and proper crop selection, is expected to restore degraded peatlands.

Degraded peatlands need to be saved so that further land deteoriation does not occur. Agroforestry systems can be an option for restoring degraded peatlands. The agroforestry system is a cropping pattern that uses a combination of forestry plants (trees) with agricultural crops (seasonal), which aims to obtain maximum results without neglecting aspects of land conservation and practical cultivation of local communities [2]. Peatland degradation causes changes in the function of peatlands both as a medium for growing plants and the environment. Degraded peatlands are more susceptible to land fires and carbon emissions, so caution is needed in the use of these lands. The agroforestry system can be applied to community-owned peatlands and production forest areas. The purpose of this paper is to describe the revegetation restoration of degraded peatlands using agroforestry systems.

\section{Degraded peatlands}

Degraded peatlands are peatlands that have been converted from natural forest to other areas that are not utilized and are experiencing a decline in both their function as a growth medium and an environmental function. Based on PP 71 of 2014 in conjunction with PP 57 of 2016 damage to the peat ecosystem in cultivation areas occurs when the water level is more than $0.4 \mathrm{~m}$ below the peat surface and/or exposure to pyrite sediment and or quartz sand under the peat layer. The degraded peat layer is generally hydrophobic, making peat soils dry, making them very susceptible to land fires.

Degradation of natural forests or peatlands in Indonesia are generally caused by several factors, among others; illegal logging, encroachment, forest and peatland fires, construction of drains or drainage in peatlands that are not well calculated, weak and lack of public awareness and understanding of the beneficial functions of peat swamp forests [3]. The conversion of peatland in Indonesia mostly emits $\mathrm{CO}_{2}$ or peat decomposition which is greater than the initial condition of the land, namely primary forest. Land conversion to acacia plantations contributed the most to peat decomposition compared to other land changes, followed by oil palm plantations $[4,5]$.

Degraded peatlands with a potential area of approximately 4.4 million hectares, of which 3.74 million hectares are covered with scrub, are very susceptible to fire. This land has the potential to be used as an agricultural area. However, the use of the land must consider the sustainability of the peat and its environmental impacts. Degraded peatlands that are not managed properly will cause further damage to the land. The degradation of peatlands causes the multifunctional capacity of the peat to decrease. The distribution of degraded land in the form of scrub and idle land is shown in Table 1.

Table 1. Degraded peatlands in Sumatra, Kalimantan and Papua

\begin{tabular}{|l|r|r|r|r|}
\hline \multicolumn{1}{|c|}{ Land use } & \multicolumn{1}{c|}{ Sumatera } & \multicolumn{1}{c|}{ Kalimantan } & \multicolumn{1}{c|}{ Papua } & \multicolumn{1}{c|}{ Total } \\
\hline Shrubs & 233.282 & 80.566 & 88.496 & 402.349 \\
\hline Bush & 1.293 .543 & 1.293 .097 & 249.533 & 2.836 .221 \\
\hline Idle land & 378.551 & 187.447 & 13.905 & 579.913 \\
\hline Savana & 89.143 & 2 & 66.921 & 156.068 \\
\hline Total & & & & 3.974 .551 \\
\hline
\end{tabular}

Source: [6 - 8] 
Utilization of degraded peatlands requires principles for the use of environmentally friendly and sustainable peatlands. Unfavorable biophysical land conditions are a problem that must be resolved. Physical, chemical, and biological characteristics of peat soil do not support the growth of introduced plants, so it is necessary to improve soil fertility for optimal plant growth.

The chemical properties of peat soil include high soil acidity (low soil $\mathrm{pH}$ ), which is caused by poor leaching conditions and hydrolysis of organic acids. These organic acids are usually dominated by fulvic and humic acids [9], [10]. Low soil $\mathrm{pH}$ will affect the availability of other nutrients such as $\mathrm{P}, \mathrm{K}$ and $\mathrm{Ca}$ and a number of micro elements [11]. The cation exchange capacity (CEC) in peat soils is very high [12].

The physical properties of degraded peatlands include hydrophobic conditions that make the soil unable to absorb water again, accelerated lateral water flow, and accelerated nutrient leaching. Hydrophobicity will affect the ability of humic substances in cation adsorption [13]. The hydrophobic peat layer causes dry peat soils to be very vulnerable to land fires. Some of the physical properties of soil that distinguish hydrophobic and hydrophilic peatlands are presented in Table 2. Factors that cause irreversible drying include temperature, air humidity and water content prior to overdrain [14]. The limit of water content at the emergence of hydrophobic properties in ombrogen peat depends on the level of maturity of the peat. In sapric peat, the percentage of water content at emergence of hydrophobic properties is lower than that of hemic and fibric peat.

Table 2. The physical characteristics of peat are hydrophilic and hydrophobic

\begin{tabular}{|l|l|c|c|c|}
\hline & Physical properties & $\begin{array}{c}\text { Sapric } \\
\text { (Hydrophilic) }\end{array}$ & $\begin{array}{c}\text { Fibric } \\
\text { (Hydrophilic) }\end{array}$ & $\begin{array}{c}\text { Fibric } \\
\text { (Hydrophobic) }\end{array}$ \\
\hline 1 & Water content $(\% \mathrm{v})$ & 370,80 & 510,70 & 53,40 \\
\hline 2 & Bulk density $\left(\mathrm{g} . \mathrm{cm}^{-3}\right)$ & 0,30 & 0,13 & 0,18 \\
\hline 3. & Mass density $\left(\mathrm{g} . \mathrm{cm}^{-3}\right)$ & 1,57 & 1,07 & 1,19 \\
\hline 4 & Total pore space $(\%)$ & 83,00 & 88,00 & 85,00 \\
\hline
\end{tabular}

Source : [15]

\section{Agroforestry in degraded peatlands}

Degradation of natural forests or peatlands in Indonesia are generally caused by several factors, among others; illegal logging, encroachment, forest and peatland fires, construction of drains or drainage in peatlands that are not well calculated, weak and lack of public awareness and understanding of the beneficial functions of peat swamp forests [16], The conversion of peatland in Indonesia mostly emits $\mathrm{CO}_{2}$ or peat decomposition which is greater than the initial condition of the land, namely primary forest. Land conversion to Acacia plantations contributed the most to peat decomposition compared to other land changes, followed by oil palm plantations $[17,18]$.

Agroforestry is an alternative to restoring degraded peatlands. The background of the concept of agroforestry is land use that is not optimal, especially in production forest areas. On the other hand, the economic condition (income) of the community around the forest area is still mostly low. This often triggers activities that lead to environmental destruction. This trend of environmental destruction needs to be prevented by means of land management that can effectively preserve the physical environment and at the same time meet the needs of food, shelter and clothing for the people living around the forest. Empowerment of peatland communities around forest areas has two considerations: (1) because of the poverty and helplessness experienced by most communities on peatlands 
(often the cause of their ignorance of environmental quality), and (2) awareness and motivation to participate in land conservation (difficult to do if the basic needs of the community are still not fulfilled [19]

An agroforestry system is defined as an optimal land use method that combines short and long rotation biological production systems (a combination of forestry production and other biological production) in a manner based on the principle of sustainability, concurrently or sequentially, within the forest area or outside. with the aim of achieving people's welfare [20]. The agroforestry system can be applied to forest development through a mixed pattern of tree and seasonal crops which is carried out on communityowned peatlands and production forest areas.

The success of an agroforestry system is very dependent on tree management which can reduce adverse effects and maximize the beneficial effects both physically, economically, socially and environmentally. The tree-soil-plant interaction depends on the growth and morphology of the tree, both on the crown and root of the plant [19]. In addition, the types of plants under standing that can support the improvement of physical, economic, social and environmental conditions need to be considered. The advantages of agroforestry systems include; land optimization, crop diversification, reduce the risk of failure, can also prevent land preparation for annual crops without burning, increase carbon stock.

This agroforestry system is suitable for restoring peatlands both ecologically and economically. Agroforestry systems can optimize the use of existing local resources, by combining various components of the farming system (plants, animals, soil, water, climate, and humans) so that they complement each other and provide the greatest synergy effect. Agroforestry systems use small amounts of external inputs, only needed to supplement the elements that are lacking in the ecosystem and increase biological, physical and human resources; utilization of external inputs gives major attention to efforts to maximize recycling and minimize environmental damage.

Management of agroforestry systems is always faced with various challenges such as high levels of shade and the possibility of competition for space, water, nutrition, and humidity. The choice of intercropping types that are suitable for staple crops is important in agroforestry systems. The suitability of plants can be determined from the physiological conditions of the tree, such as the crown and roots, which affect the ideal spacing. Types of seasonal plants that can be planted under jelutong stands up to the 6th year include: chilies, leeks, mustard greens, and corn [21].

The successful development of plant species on peat will be highly dependent on soil conditions. Several alternative types of plants that can be developed on peatlands according to land conditions are presented in Table 3. Utilization of the lower part of tree stands for plant cultivation can only be done by using cropping patterns and land arrangement so that there is no competition for sunlight and nutrient elements.

Table 3. Area conditions and alternative types of plants on peatlands (Modified from: [22])

\begin{tabular}{|c|c|c|c|}
\hline No & Land conditions & Alternative types of tree plants & $\begin{array}{l}\text { Types of plants carried } \\
\text { by tree stands }\end{array}$ \\
\hline 1. & $\begin{array}{l}\text { Areas of mild / } \\
\text { moderate burns, } \\
\text { clear cutting, and } \\
\text { open areas (sparse } \\
\text { vegetation) }\end{array}$ & $\begin{array}{l}\text { 1. Jelutung rawa (Dyera } \\
\text { polyphilla) } \\
\text { 2. Perepat (Combretocarpus } \\
\text { rotundatus) } \\
\text { 3. Belangiran (Shorea } \\
\text { belangeran) } \\
\text { 4. Pulai rawa (Alstonia } \\
\text { pneumotophora) }\end{array}$ & $\begin{array}{l}\text { 1. Types of secondary } \\
\text { crops } \\
\text { 2. Types of horticulture } \\
\text { 3. Rice } \\
\text { 4. pineapple (Ananas } \\
\text { comusus Merr), } \\
\text { 5. Aloe vera }\end{array}$ \\
\hline
\end{tabular}




\begin{tabular}{|c|c|c|c|}
\hline & & $\begin{array}{l}\text { 5. Rengas manuk (Syaggium } \\
s p \text { ) } \\
\text { 6. Terentang (Campnosperma } \\
\text { coriacea) }\end{array}$ & \\
\hline 2. & $\begin{array}{l}\text { Burnt areas that } \\
\text { have undergone } \\
\text { succession, selective } \\
\text { logging areas, } \\
\text { moderate closure } \\
\text { areas }\end{array}$ & $\begin{array}{l}\text { 1. Meranti rawa (Shorea } \\
\text { pauciflora, Shorea } \\
\text { tysmanniana, Shorea } \\
\text { uliginosa) } \\
\text { 2. Durian (Durio carinatus) } \\
\text { 3. Ramin (Gonystylus } \\
\text { bancanus) } \\
\text { 4. Kempas (Koompassia } \\
\text { malaccensis ) } \\
\text { 5. Resak (Vatica rassak) } \\
\text { 6. Kapur Naga (Calophyllum } \\
\text { 7. macrocarpum) } \\
\text { 8. Nyatoh (Palaquium spp.) } \\
\text { 9. Bintangur (Calaphyllum } \\
\text { Hosei) }\end{array}$ & \\
\hline 3. & $\begin{array}{l}\text { Selective logged } \\
\text { areas, where there } \\
\text { are still many trees, } \\
\text { the area of } \\
\text { vegetation cover is } \\
\text { still high }\end{array}$ & $\begin{array}{l}\text { 1. Meranti rawa (Shorea } \\
\text { pauciflora, } \\
\text { 2. Shorea tysmanniana, } \\
\text { Shorea uliginosa) } \\
\text { 3. Ramin (Gonystylus } \\
\text { bancanus) } \\
\text { 4. Punak (Tetramerista glabra } \\
\text { ) } \\
\text { 5. Balam (Palaquium } \\
\text { rostratum) } \\
\text { 6. Kempas (Koompassia } \\
\text { malaccensis) } \\
\text { 7. Gemor (Nothaphaebe } \\
\text { Cariacea) }\end{array}$ & \\
\hline
\end{tabular}

The combination of tree and seasonal crops can maintain production so that the sustainability of farming income is more secure. Jelutung has the potential to be used as a tree crop in agroforestry systems to restore degraded peatlands [19]. The combination of jelutong with corn, mustard greens, chilies or leeks can be applied in degraded peatlands. The results of the economic analysis indicated by the value of the $\mathrm{B} / \mathrm{C}$ ratio, that the combination of jelutong + corn + chilli + onion gave greater benefits (Table 4$)$.

Table 4. Results of economic analysis of jelutong-based agroforestry systems with maize and horticulture (Source, [23])

\begin{tabular}{|l|c|c|c|c|c|}
\hline No & Plant type & $\begin{array}{c}\text { Revenue } \\
(\mathrm{Rp} / \mathrm{ha})\end{array}$ & $\begin{array}{c}\text { Cost } \\
(\mathrm{Rp} / \mathrm{ha})\end{array}$ & $\begin{array}{c}\text { Benefit Value } \\
(\mathrm{Rp} / \mathrm{ha})\end{array}$ & $\mathrm{B} / \mathrm{C}$ \\
\hline 1 & $\begin{array}{c}\text { Jelutung+ corn + mustard } \\
+ \text { chili }\end{array}$ & 97510.500 & 27.600 .000 & 69.910 .500 & 3,5 \\
\hline 2 & $\begin{array}{c}\text { Jelutung+ corn + mustard } \\
\text { greens + leek }\end{array}$ & 94.629 .250 & 20.900 .000 & 73.729 .250 & 4,5 \\
\hline
\end{tabular}




\begin{tabular}{|c|c|c|c|c|c|}
\hline 3 & $\begin{array}{c}\text { Jelutung+ corn + chilies + } \\
\text { leek }\end{array}$ & 92.878 .750 & 29.825 .000 & 71.978 .750 & 3,1 \\
\hline 4 & $\begin{array}{c}\text { Jelutung+ mustard + chilli } \\
+ \text { leek }\end{array}$ & 93.369 .250 & 26.000 .000 & 67.369 .250 & 4,0 \\
\hline
\end{tabular}

\section{The role of agroforestry to mitigate carbon emissions in degraded peatlands}

Peatlands play an important role in mitigating GHG emissions nationally. Sources of GHG emissions in the agricultural and land use sectors include (1) $\mathrm{CO}_{2}$ from deforestation and changes in land use for agriculture (emissions and sequestration); (2) $\mathrm{CO}_{2}$ from peat decomposition; (3) $\mathrm{CO}_{2}$ organic matter from mineral soils and peatland fires; (4) $\mathrm{CH}_{4}$ from paddy fields; (5) $\mathrm{N}_{2} \mathrm{O}$ from $\mathrm{N}$ fertilizer and livestock manure, and (6) $\mathrm{CH}_{4}$ from saltpeter (burb) and livestock manure [1]. Land conversion and illegal timber extraction are rampant, causing degraded peat forest lands in Southeast Asia, especially in Indonesia and Malaysia [24]. This land degradation causes primary peat swamp forest to turn into vast expanses of secondary forest, plantations or just alang-alang grass land. Therefore, strategic steps are needed to mitigate carbon emissions in peatlands.

Agroforestry can be developed in various land conditions, both wet and dry areas. Planting trees with shrubs under tree stands will increase the absorption of $\mathrm{CO}_{2}$ from the decomposition of peat matter, thereby reducing carbon emissions in the atmosphere. Furthermore, it will increase the carbon stock above the soil surface by using $\mathrm{CO}_{2}$ for photosynthesis and producing plant biomass. In general, the short life plant biomass average is very low, which is below $10 \mathrm{~kg}$ per individual plant. This means that throughout the life of the plant, the need for $\mathrm{CO}_{2}$ consumption is estimated at only 104-105 $\mathrm{CO}_{2}$ molecules [25]. On the other hand, agroforestry practices usually use $50-70 \%$ perennials (plantation crops, fruit trees and forest plants). Perennials generally have plant biomass above $50 \mathrm{~kg}$ per individual plant, which means that the need for $\mathrm{CO}_{2}$ consumption is far above $5 \times 105$ molecules. These results show that the agroforestry agricultural model has the greatest contribution to the absorption of $\mathrm{CO}_{2}$ from the earth's atmosphere, if this pattern is applied appropriately and with quality management [26].

Long-lived tree crops that live in forests and agroforestry land store more carbon than annual crops. Therefore, natural forests with a wide variety of long-lived tree species and litter are high carbon stores. When forests are converted into agricultural land or plantations, the storage quantity $\mathrm{C}$ will decrease. Along with GHG mitigation efforts, it is necessary to do so to reduce the release of $\mathrm{CO}_{2}$ into the air. Maintaining natural forest ecosystems, planting trees on degraded peatlands that are already used for agriculture, is essential to reduce carbon emissions. If agroferstry replaces forest, the effect on GHG emissions is negative, but the effect is still more positive when compared to 'idle peatland' unutilized/open peatlands. The important role of agroforestry as a carbon stock is one of the hopes in efforts to mitigate GHG emissions and improve the economy of communities around forest areas. By involving the community in the management of degraded forests and peatlands, in several areas the success rate has been shown to be higher, because the community has a stake in the existence of forests and land [27]. 


\section{Conclusion}

Degraded peatlands need to be restored that could impact the environmental and socioeconomic quality of the surrounding community. One of the ways to restore degraded peatlands can be done through revegetation. Agroforestry systems can be developed to restore degraded peatlands through planting forest and seasonal crops. The role of agroforestry in mitigating GHG emissions in degraded peatlands through its function as a carbon sink and reducing the danger of land fires due to the exploitation of degraded peatlands. Agroforestry is expected to be one of the solutions for climate change mitigation, because besides being able to meet the short-term needs of the community so that the pressure on exploitation of forest land is reduced, it is also a potential source of carbon storage.

\section{References}

1. F. Agus. Antisipasi Perubahan Iklim Sektor Pertanian in Sosialisasi Dampak Perubahan Iklim 28 Agustus 2014. Banjarmasin (2014). [Bahasa Indonesia].

2. I. Anggraeni, Wibowo, A. Pengaruh Pola Tanam Wanatani Terhadap Timbulnya Penyakit dan Produktivitas Tanaman Tumpangsari. Bulletin Info Hutan Tanaman, Pusat Penelitian dan Pengembangan Hutan Tanaman. Jakarta (2007).

3. Antonius. PIPER. 23,12:136-146(2016). [Bahasa Indonesia].

4. F. Marchante, A. Kjøller, S. Struwe, H Freitas. Applied Soil Ecology. 40:210 217(2016).

5. K. Hergoualc'h, L. V. Verchot. Mitig. Adapt. Strateg. Glob. Chang. 19:789807(2013).

6. S. Ritung, Wahyunto, Nugroho, K. Sukarman, Hikmatullah, Suparto, C. Tafakresnanto. Peta Lahan Gambut Indonesia Skala 1:250 000 (Indonesian peatland map at the scale 1:250 000) Bogor, Indonesia (2001).

7. Kementerian Kehutanan. Penutupan Lahan di Indonesia. Kementerian Kehutanan. Jakarta (2011).

8. Wahyunto, K. Nugroho, S. Ritung, Y. Sulaiman. Indonesian peatland maps; methods, certainty and uses in Prosiding Seminar Nasional Pengelolaan Berkelanjutan Lahan Gambut Terdegradasi untuk Mitigasi Emisi GRK dan Peningkatan Nilai Ekonomi. BBSDLP. Bogor (2014).

9. I.P.G. Widjaja-Adhi. Masalah Tanaman Di Lahan Gambut in Pertemuan Teknis Penelitian Usahatani Menunjang Transmigrasi. Cisarua, Bogor, 27-29 Februari 1988. p. 16 (1988).

10. A. Rachim. Penggunaan kation-kation polivalen dalam kaitannya dengan ketersediaan fosfat untuk meningkatkan produksi jagung pada tanah gambut. Disertasi. Program Pascasarjana IPB. Bogor. p. 268 (1995).

11. H. Marschne. Mineral Nutrition of Hogher Plants. Acc Press. Harcourt Jovanovich Publishers. London, San Diego, New York, Berkeley, Boston, Sydney, Tokyo, Toronto. p. 673 (1986).

12. W. Hartatik, D.A. Suriadikarta. Teknologi Pengelolaan Hara Lahan Gambut in Karakteristik dan Pengelolaan Lahan Rawa, I. Las (eds). Balai Besar Penelitian dan Pengembangan Sumberdaya Lahan Pertanian. Bogor (2006).

13. J. Chorover, M. K. Amistadi, W.D. Burgos, P. G. Hatcher. Soil Sci. Soc. Am. J. 63:850-857(1999).

14. U. Buczko, O. Bens. Soil Sci. Soc.Am.J 70;718-727(2006). 
15. A. Supriyo, A. Maas. Leahing impact on chemical properties of different reclamation stage of ombrogenous peat. Paper Presented at International Symposium and Workshop Restoration and Wise Use of Tropical Peatland:"Problem of Biodiversity Fire, Poverty and Water Management" held in Palangkarya, at Sep $21-24$ (2005).

16. Antonius. PIPER. 23,12:136-146(2016). [Bahasa Indonesia].

17. F. Marchante, A. Kjøller, S. Struwe, H. Freitas. Applied Soil Ecology. 40:210217(2008).

18. K. Hergoualc'h, L. V. Verchot., L.V. Mitig. Adapt. Strateg. Glob. Chang. 19:789807(2013).

19. Harun, M.K. Agroforestri Berbasis Jelutung Rawa.Solusi Sosial, Ekonomi, dan Lingkungan Pengelolaan Lahan Gambut. Forda Press. 254 hal. (2014). [Bahasa Indonesia].

20. Lahjie, A.M. Teknik Agroforestri. Penerbit UPN "Veteran Jakarta" (GrafikaUPNVJ), Jakarta. p. 329 (2001).

21. D. Alimah, Junaidah, M.K. Harun. Produktivitas dan system perakaran jelutung rawa (Dyera polyphylla) di lahan agroforestry in Prosiding Seminar Nasional Agroforestry (2015).

22. KLHK. Pedoman Pemulihan Ekosistem Gambut. KLHK. Jakarta. pp. 39. (2015)

23. D. Itta, Asysyifa, T. Satriadi. Karakteristik lahan gambut dan pola agroforestri di kelurahan Kalampangan kota Palangkaraya, Kalimantan Tengah in Prosiding Seminar Nasional Agroforestry (2015)

24. J. Miettinen, A. Hooijer, C. Shi, D. Tollenaar, R. Vernimmen, S.C. Liew, C. Malins, S.E. Page. GCB Bioenergy. 4:908-918(2012).

25. T. T. Kozlowski, S. G. Pallardy. Physiology of Woody Plants 2 nd Ed. Academic Press. San Diego (1995).

26. A. Widyianto. Mitigasi Perubahan Iklim melalui Agroforestri. Sebuah persepsi. ResearchGate (2011). https://www.researchgate.net/publication/299753479

27. PPPSEKPI. Policy Brief. 9,4(2015). 